\title{
Technologization of the Teachers Coping behavior formation as management and staff training means
}

\author{
Tatiana Gudina ${ }^{1}{ }^{*}$ Valentina Ponikarova ${ }^{1}$, Irina Bukina ${ }^{1}$ \\ ${ }^{1}$ Cherepovets State University, Cherepovets, Russia \\ *Email: gtv1968@mail.ru
}

\begin{abstract}
An inclusive approach to teaching people with disabilities and/or disabilities is now considered one of the main strategic paradigms of modern education. In this regard, the question arises about the importance of professional training of pedagogical personnel implementing the inclusive practice, considering the orientation of sociopedagogical interaction, professionally essential qualities, risk factors, typologies, and strategies of coping behavior, as a mental neoplasm that can not only solve problematic situations but also change a person's individuality. Depending on personal and professional development characteristics, the authors identified and described several leading types of coping behavior, and typology was carried out according to the following criteria: coping strategies, coping resources, coping techniques, and coping behavior productivity. Profiling teachers (and other specialists) coping behavior will allow identifying (based on observation, diagnosis, expert assessment) teachers at risk, developing preventive measures and preventing professional deformation at different stages of personality development.
\end{abstract}

Keywords: A typology of coping behavior, Profiling, Educational technology.

\section{INTRODUCTION}

Currently, the concept of "coping behavior " is considered as a separate way of interacting with a situation following its logic, significance in a person's life and psychological capabilities. Coping behavior involves adapting to circumstances in a problematic situation when the available means, methods, and personal resources cannot resolve the conflict.

Such a situation for teachers is a professional activity in an inclusive educational space, which acts as a system of interaction of participants in the educational process, ensuring the full inclusion of a child with disabilities in education through the implementation of educational and interpersonal relationships between all subjects and levels of the educational space. This leads to a change in the social conditions of teachers' development and the emergence of coping behavior as a mental neoplasm that can resolve difficult circumstances and change a person's personality.

\section{MATERIALS AND METHODS}

Currently, it seems relevant to use educational and psychological technologies (technologization) of the management process and personnel training, the main features of which are standardisation, unification, and creativity, combined with hierarchy.

The specificity of educational technologies used to solve strategic pedagogical tasks is manifested in the fact that they are associated with the individual's consciousness, the presence of the probabilistic nature of the educational impact, the need to consider several other aspects of the problem.

The analysis of psychological and pedagogical literature allowed us to identify the problem of research, the purpose of which is to study the features of coping behavior of teachers in an inclusive educational space, as well as the development and refinement of diagnostic tools using profiling (profiling) of their coping behavior. 
Profiling means a set of psychological methods for assessing and predicting human behavior based on the analysis of his appearance, nonverbal and verbal signs.

Recently, businesses have increasingly taken up profiling, helping owners and top managers of companies assess the intentions and reliability of the statements of their employees, partners, and customers. There were also separate areas of profiling: aviation profiling, railway profiling, hotel, personnel, business profiling.

In this study, scientific interest is represented by the works of authors who reveal the methodological basis for the study of coping behavior, such as Amirkhan, J.H. [1], Breakwell G.M. [2], Frydenberg, Lewis R. [3]; Lazarus, R.S. [4]; the study of profiling in psychology and business was carried out by Ekman P., Friesen W.V., Scherer K.R. [5]; Ressler R., Burgess A., Douglas J. [6]; Rossmo D.K. [7]; Zuckerman M., DePaulo B.M., Rosenthal R.[8]; Volchetskaya T.S., Abramovsky A.A. [9]; M.A. Kovalenko [10]; T.G. Martseva [11]; Yu.G. Odegov [12]; E.A. Petrov [13].

To probe the features of teachers coping behavior of inclusive education, undergraduate and graduate students, we used the author's technology based on such diagnostic techniques as the questionnaire "coping behavior methods" (according to R. Lazarus and S. Folkman) [14]; determination of individual coping strategies (according to E. Heim) [14]; leading ways to overcome professional difficulties in the field of inclusive education (according to V.N. Ponikarova) [15]; expert assessment "The level of risk in professional activity" (according to E.V. Zmanovskaya) [14], which made it possible to identify the original typologies of coping behavior .

Profiling teachers (and other specialists) coping behavior will allow identifying (based on observation, diagnosis, expert assessment) teachers at risk, developing preventive measures and preventing professional deformation at different stages of personality development.

The study was conducted in the period from 2019 to 2021 on the territory of the Vologda region, which was attended by 200 teachers engaged in inclusive pedagogical practice in educational institutions of Vologda and Cherepovets, as well as undergraduate students and graduate students (200 people).

\section{RESEARCH RESULTS}

We have identified and described several leading types of coping behavior of teachers of inclusive education (pedagogical system of formation of soft skills), typology of which was carried out according to the following criteria: coping strategies, coping resources, coping techniques and productivity of coping behavior .

Coping strategy is a line of human behavior in resolving a difficult situation. The following are most often described among coping strategies: problemsolving, seeking social support, and avoidance.

Coping resources are external and internal variables that contribute to psychological stability in "difficult" situations. Traditionally, such coping resources as the level of subjective control, Self-concept, selfactualisation, etc., are allocated.

We paid attention to other coping resources: assertiveness, alertness, ego-state, flexibility/rigidity, tolerance/conflict.

Coping techniques are the most personality-specific patterns of coping behavior in specific situations of social and/or professional interaction. Among the coping techniques, we have identified the following: interaction, compromise-minus, compromise-plus, withdrawal, confrontation.

The productivity of coping behavior is the degree of effectiveness of resolving problematic situations; according to this criterion, the following varieties are traditionally distinguished: productive and nonproductive.

Productive coping behavior is a type of coping behavior in which the resolution of a problem situation is achieved mainly using flexible, adequate patterns of coping behavior.

Non-productive coping behavior is a non-productive type of coping behavior. The resolution of the problem situation is achieved mainly using rigid, stereotypical, inadequate patterns of coping behavior.

Based on the diagnostic data obtained, qualitative characteristics of the types of coping behavior in the experimental group were proposed, which are presented in Table 1.

A comparative study of the typology of coping behavior of respondents showed that such types of coping behavior prevail among teachers as smash $17 \%$, adaptive $-32 \%$; the following types of coping are most common among bachelors: creative - $20 \%$ and adaptive - 40\%; the adaptive type prevails among graduates $-40 \%$.

There are general types of undergraduate and graduate students - $20 \%$ of the subjects have neutral status, i.e. an indefinite type of coping.

The least represented type of coping behavior is crush, an non-productive type of coping. 
Table 1. Typology of coping behaviour

\begin{tabular}{|c|c|c|c|c|}
\hline $\begin{array}{l}\text { Type of coping } \\
\text { behaviour }\end{array}$ & $\begin{array}{l}\text { Leading Coping } \\
\text { strategies }\end{array}$ & $\begin{array}{l}\text { Leading coping } \\
\text { resources }\end{array}$ & $\begin{array}{c}\text { Leading coping } \\
\text { technics }\end{array}$ & Productivity \\
\hline smash & Solving the problem & Assertiveness & Interaction & Productive \\
\hline creative & Solving the problem & Alertness & $\begin{array}{c}\text { Compromise - } \\
\text { plus }\end{array}$ & $\begin{array}{l}\text { Conditionally } \\
\text { productive }\end{array}$ \\
\hline adaptive & $\begin{array}{c}\text { Search for social } \\
\text { support }\end{array}$ & Ego state & $\begin{array}{c}\text { Compromise - } \\
\text { minus }\end{array}$ & $\begin{array}{c}\text { Conditionally } \\
\text { productive }\end{array}$ \\
\hline crush & Avoidance & Tolerance & $\begin{array}{c}\text { Care / } \\
\text { confrontation }\end{array}$ & $\begin{array}{c}\text { Conditionally } \\
\text { productive/non- } \\
\text { productive }\end{array}$ \\
\hline neutral & $\begin{array}{c}\text { Search for social } \\
\text { support }\end{array}$ & Ego state & $\begin{array}{c}\text { Compromise - } \\
\text { minus }\end{array}$ & Productive \\
\hline
\end{tabular}

\section{RESULTS DISCUSSION}

Based on the data obtained, we have developed an educational technology designed for inclusive education teachers "Coping profile". The same technology has been adapted for undergraduate and graduate students.

The purpose of the technology is to profile and shape the inclusive education teachers coping behavior.

Technology objectives:

- To introduce teachers to the phenomenology of coping behavior and elements of profiling.

- To form components of professional productive coping behavior, including coping strategies, resources, techniques, etc.

- Develop and test a workbook that covers: profiling of coping behavior; establishing a readiness to implement inclusive educational practice; development of professional coping behavior; formation of soft skills of teachers.

- Prepare methodological recommendations for the implementation of this technology in educational organisations.

We have used the following types of training:

- subjective, including personal and epistemological training, which determines the formation of a focus on self-education, self-development, cooperation, reflexive attitude to one's level of competence and implemented activities;

- theoretical training, which determines the possession of terminology, orientation in the categorical apparatus, the essential aspects of the problem field of coping behavior;
- empirical - determining readiness to implement practical actions on the use of formed personal resources and patterns of coping behavior to resolve problematic situations during professional activity and reflection on one's profile of coping behavior.

The identification of the technology is presented in Table 2 .

We used the following as the basic principles of technology implementation:

- the principle of consistency, which determines the content of individual educational modules and technology as a whole;

- the principle of completeness correlates with the requirements of professional and educational standards;

- the principle of targeted unity - orients the orientation of technology components to the formation of a professional;

- the principle of subject content implies the selection of the necessary and sufficient content of educational material;

- the principle of priority of simultaneous results of technology implementation;

- the principle of unity of theory and practice of teaching.

Classes (modules) for teachers included the following topics: "Modern approaches to understanding coping behavior ", "Specifics of coping behavior of teachers", "Methodology and methodology of profiling coping behavior ", "Educational and psychological technologies", "Current technologies of coping behavior formation".

As an organisational unit for the implementation of the technology for the formation of coping behavior of 
Table 2. Identification of the "Coping Profile" technology

\begin{tabular}{|l|l|}
\multicolumn{1}{|c|}{\begin{tabular}{c}
\multicolumn{1}{c|}{ Classification } \\
system
\end{tabular}} & \multicolumn{1}{c|}{ Technology identification } \\
\hline Application-level & Meta technology \\
\hline Philosophical basis & Profiling \\
\hline Methodological approach & Sociogenic \\
\hline The leading factor of personality development & Activity \\
\hline The scientific concept of experience development & Self-development technology \\
\hline Orientation to the contexts of personal development & Personality-oriented \\
\hline The nature of the content & Developing technology \\
\hline Type of pedagogical activity & Cyclical \\
\hline Type of control & Developing methods \\
\hline Methods & Group training \\
\hline Organisational forms & Effective and practical \\
\hline Means of education and upbringing & Educational technology \\
\hline Approaches & Based on the activation and intensification of the \\
\hline The direction of modernisation & activities of the subjects \\
\hline Category of pedagogical objects & Advanced level technology \\
\hline
\end{tabular}

teachers, we have adopted as a basis an educational module, which includes: a workshop, several trainings (usually two), a consultation. If necessary, the ratio of activities may change.

The first module assumes the following structure: two workshops and two trainings. They can go exactly in this order, but alternation is also possible: workshop workshop - training - workshop - training. If there is a social request, a consultation can be held, occupying any place in the module's structure.

Subsequent modules, as a rule, have the structure already described: workshop (lecture), several trainings (usually two), consultation.

The result of implementing the technology is a business game, which is a test event, if possible, can be supplemented with a final conference.

The formation of coping behavior among teachers was carried out within the framework of workshops and masterclasses; students implemented an elective course that combined traditional methods, techniques and forms of teaching with innovative ones: brain-ring, panel discussion, flash workshop, master-seminar, case method, etc.

We developed a workbook within the elective course "PRO-coping" framework during the implementation and testing of educational technology, which was used as methodological support.
The notebook includes three to four parts, which conditionally correspond to the subject of educational modules and contains a diagnostic part, a profiling tool.

The educational part contains a small amount of information on the corresponding module, exercises, tasks, reflection, a dictionary of basic concepts. Presentations on each educational module have been developed and tested.

\section{CONCLUSION}

Thus, the technologization of the process of forming coping behavior using profiling elements provides accurate instrumental management of the educational process and guaranteed success of the goals set and timely identification of teachers at risk, prevention of unfavourable types of coping.

This allows you to: analyse and systematise practical experience and its use on a scientific basis; comprehensively solve educational and socioeducational tasks; use available resources; choose the most effective, and develop new technologies and models to solve emerging socio-pedagogical problems in the field of profiling coping behavior.

\section{REFERENCES}

[1] J.H. Amirkhan, Factor analytically derived measure of coping: the strategy indicator, 
Personality and Social Psychology 59 (1990) 10661074.

[2] G.M. Breakwell, Copying with threatened identities, L.; N.Y.: Routledge, 1986, 280p.

[3] £. Frydenberg, R. Lewis, Teaching Coping to adolescents: when and to whom? American Educational Research Journal, Fall 37(3) (2000) 727-745.

[4] R.S. Lazarus, Psychological stress and the Coping in Aging, American Psychologist 38 (1983) 245254.

[5] P. Ekman, W.V. Friesen, K.R. Scherer, Body movement and voice pitch in deceptive interaction, Semiotica 16 (1976) 23-27.

[6] R. Ressler, A. Burgess, J. Douglas, Criminal Profiling Research on Homicide, Unpublished Research Report. N.Y., 1982, pp. 34-37.

[7] D.K. Rossmo, Geographic profiling in cold cases, Cold case homicides: practical investigative techniques. Boca-Raton, 2017, pp. 559-582.

[8] M. Zuckerman, B.M. DePaulo, R. Rosenthal, Verbal and nonverbal communication of deception, Advances in experimental social psychology 14 (1981) 1-57.

[9] T.S. Volchetskaya, A.A. Abramovsky, Criminalistic profiling in Russia and abroad [Kriminalisticheskij profajling $\mathrm{v}$ Rossii i za rubezhom], Proceedings of Tula State University. Economic and Legal Sciences [Izvestiya Tul'skogo gosudarstvennogo universiteta. Ekonomicheskie i yuridicheskie nauki] 4(2) (2018) 3-8.

[10] M.A. Kovalenko, The role of observation as a professionally important quality of museum security profilers, Scientific Notes of the Russian State Social University [Rol' nablyudatel'nosti kak professional'no vazhnogo kachestva profajlerov sluzhby bezopasnosti muzeev, Uchenye Zapiski Rossijskogo Gosudarstvennogo Social'nogo Universiteta], 18-3(152) (2019) 34-42. DOI: https://doi.org/10.17922/2071-5323-2019-18-3-34$\underline{42}$

[11] T.G. Martseva, Commercial Profiling as a management technology [Kommercheskij profajling kak tekhnologiya upravleniya], Society and Law [Obshchestvo i pravo] 2(48) (2014) 292294.

[12] Yu.G. Odegov, Audit and personnel controlling [Audit i kontrolling personala], Moscow: Exam Publishing House [Moskva: Izdatel'stvo «Ekzamen»], 2004, 544 p.
[13] E.A. Petrova, Visual psycho semiotics of communication [Vizual'naya psihosemiotika obshcheniya], Moscow: Academy of Imagology [Moskva: Akademiya imidzhelogii], 2015, 320 p.

[14] Yu.A. Kleiberg, Social Psychology of deviant behavior [Social'naya psihologiya deviantnogo povedeniya], Moscow: Sphere [Moskva: TC Sfera], 2004, pp. 141-189.

[15] V.N. Ponikarova, Pedagogical system of soft skills formation: monograph [Pedagogicheskaya sistema formirovaniya soft skillz: monografiya], Kursk: publishing house of CJSC "University Book" [Kursk: izd-vo ZAO «Universitetskaya kniga»], 2020, pp. 41-50. 